A F R I C A N M I L I T A R Y S T U D I E S ・ Volume 3

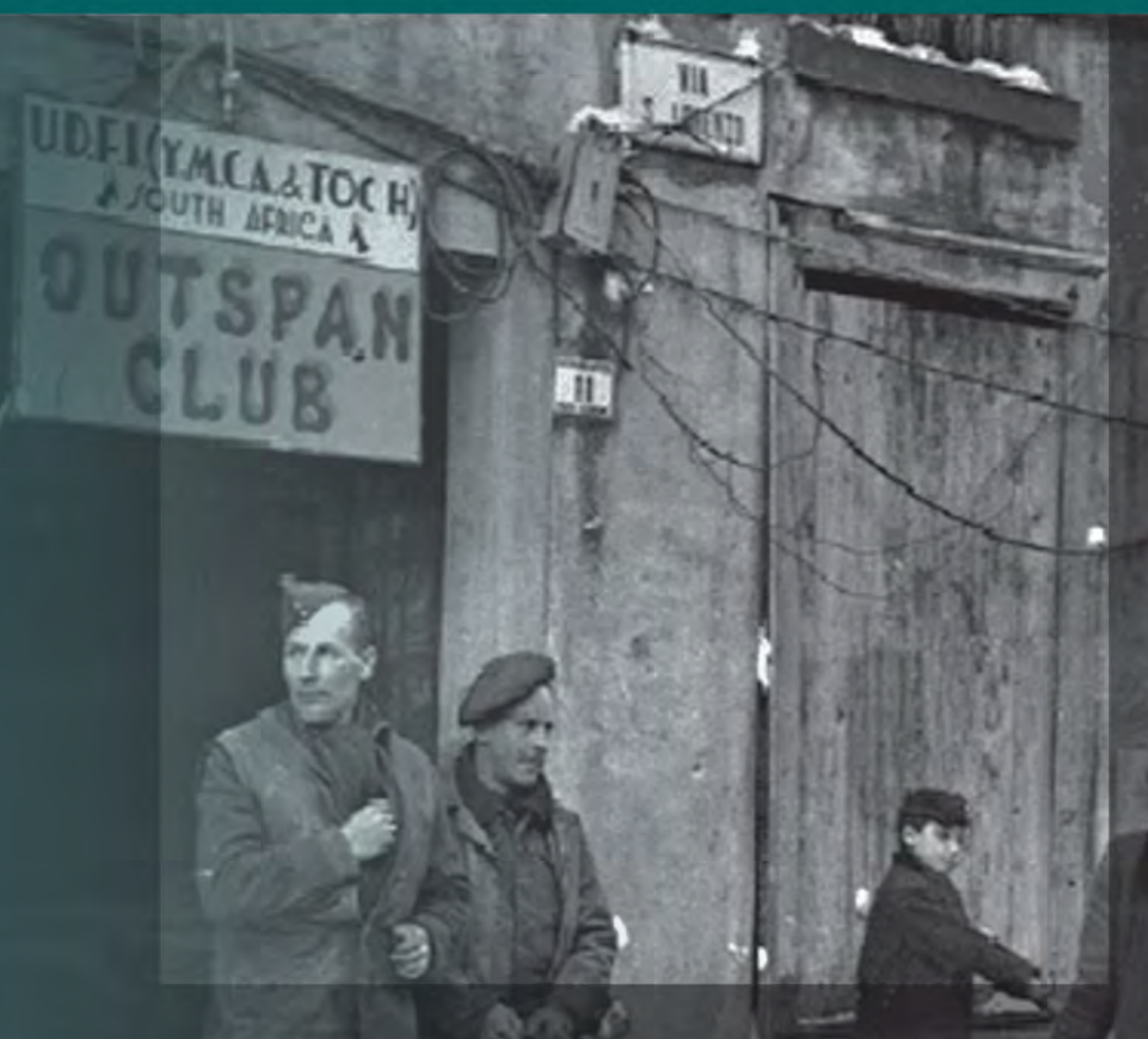

Sights, Sounds,

Memories

South African Soldier Experiences

of the Second World War 


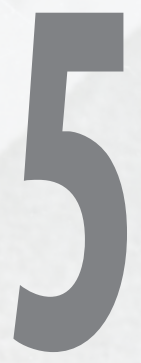

\section{ERIC AXELSON AND THE HISTORY OF THE SIXTH SA ARMOURED DIVISION IN ITALY, 1943-1945}

\section{Ian van der Waag}




\section{INTRODUCTION}

One day in December 1943 Lt Col EG Malherbe, Director of Military Intelligence, asked me, 'Would you like to go to the Mediterranean?' The 6 SA Armoured Division was finishing training in Egypt; it would soon be in combat, and it was felt by some senior officers at Defence Headquarters in Pretoria that somebody who knew something about history should go with it, to record its activities. My answer was a quick 'Yes'.'

Eric Axelson (1913-1998), known already in 1943 as an historian of Portuguese Africa, was born in London, the son of an English mother and a Swedish father. $\mathrm{He}$ came to South Africa with his parents in 1921. After studies at the Natal University College, he obtained a doctorate at the University of the Witwatersrand in 1939 under the supervision of Prof. Leo Fouché. ${ }^{2}$ This was published as South-East Africa 1488-1530 in 1940, the year Axelson took up a junior lectureship at Wits. ${ }^{3}$ But the war intervened. Following the path of other South African academics - including men like Leo Marquard and Guy Butler - Axelson became an information officer in the Union Defence Force (UDF). ${ }^{4}$ In this capacity he served first in the $3^{\text {rd }}$ South African Infantry Brigade, then at the Air School in Kimberley, and then as an education officer in the Middle East. ${ }^{5}$

In December 1943, following Malherbe's prompt, Axelson answered a notice in the newspapers advertising the position at Historical Records. Captain John AgarHamilton, head of War History, replied with an offer. The duties were threefold: 'to "encourage" units to prepare proper War Diaries and to see that they are duly sent back each month; to collect as much back history and historical material as you can and, of course, to "make history" for the Div'. ${ }^{6}$ Axelson's staff would comprise a photographer (sergeant) and a clerk (corporal) and he would have a vehicle on his establishment, although, as Agar-Hamilton explained, he was 'not altogether sanguine about [his] getting it'. ${ }^{7}$ Agreeing to these conditions, Axelson joined the $6^{\text {th }}$ SA Armoured Division, then still in Egypt, as its recording officer.

Very little detailed work has appeared on the War History Section, or the later Union War Histories. The article 'How the story of the South African experience in the Italian campaign was recorded - and distorted", which mentions Axelson specially, is a recent exception. ${ }^{8}$ In the wider literature, there are also several charming vignettes of Axelson and his attempts to do his work. In later years, for example, he told colleagues at the University of Cape Town how he had to dart ahead to try to secure any maps the Germans might have left behind. ${ }^{9}$ Guy Butler, later professor of English in Grahamstown, recounts that he met Axelson when Axelson made his first visit to the $12^{\text {th }}$ Brigade Headquarters. He tells us how heavily burdened Axelson was, climbing down a hill, along a slippery path, 'and his pack so heavy, weighted with 
camera and war diaries'. ${ }^{10}$ Agar-Hamilton, tongue in cheek, congratulated Axelson for the way he 'got about', while reminding him that historians were scarce and that there were no 'reserves' for his position: 'you are quite irreplaceable ... I don't want any urgent signals calling for a new Recording Officer!' ${ }^{11}$ While these images may seem quaint, perhaps even delightful, they say little of the duties of an historical recording officer and the attempts to construct narratives, albeit mostly of an official nature, of the 'real' war. This chapter aims to do just this.

The chapter introduces the War History Section and places the work of the historical recording officers within this context; it analyses the work done by Axelson, as the historical recording officer of the $6^{\text {th }}$ SA Armoured Division, against the background of the environmental and organisational constraints imposed upon him; and thirdly, it examines the response to Axelson's work. In this way, Axelson is used as a lens through which to understand the work of historical recording officers more widely.

Axelson was a prolific writer. He not only drafted several manuscript histories of the Division, but also kept an activity log for his section, which was later reworked into a memoir, and he maintained a lively and informative correspondence with AgarHamilton and fellow recording officers which extended well into the post-war years. Their wartime letters, numbering many dozens, cover the years from 1943 through to 1945. They were sent via the Army Post Office, going up and down by Lodestar, and so they dodged 'both censorship and flying-boat delays. ${ }^{12}$ For this reason, perhaps, the correspondence is detailed and enjoyed a relatively rapid turnaround. His log, together with extracts from twenty-two letters received chiefly from Agar-Hamilton, was published for the SA Legion in 2001 as A Year in Italy $\cdot{ }^{13}$ The original material is in the custody of the Jagger Library at the University of Cape Town and forms the basis of the research for this chapter, supplemented by material from the Department of Defence Archives in Pretoria.

\section{THE WAR HISTORY SECTION}

The War History Section had a surprisingly complex organisation. It fell under AgarHamilton, who reported directly to Malherbe, the Director of Military Intelligence (DMI) and comprised Historical Records in Pretoria as well as a range of historical recording officers deployed around the world with the fighting services (Figure 1). ${ }^{14}$ The recording officers made up an interesting group; several had had university training, and most were already acquaintances, some friends. When Axelson joined them in February 1944, their hub was in Cairo, at Maj Gen Frank Theron's headquarters, where 'Robbie' Robinson occupied the position of Senior Recording Officer, UDF, Middle East and Central Mediterranean Forces. The Cairo staff were 
Robinson, who had been the SAAF Recording Officer in Malta, Drummond, who joined the outfit in April 1944, Dennis Etheredge, and two WAAF shorthand typists. After the fall of Rome, they moved with Theron to Italy. ${ }^{15}$ Other recording officers, stationed with dispersed formations, included Capt Tony Delius, Lt JC Pieterse, and Lt AE Trollip, whose main responsibility was the non-divisional units, while Reg Davis joined the section in July 1944. Davis had joined the gunners after graduating; he was captured at Tobruk, escaped from Italy, and, like Axelson, responded to an advertisement for a job with Agar-Hamilton. He had been one of Axelson's students. ${ }^{16}$

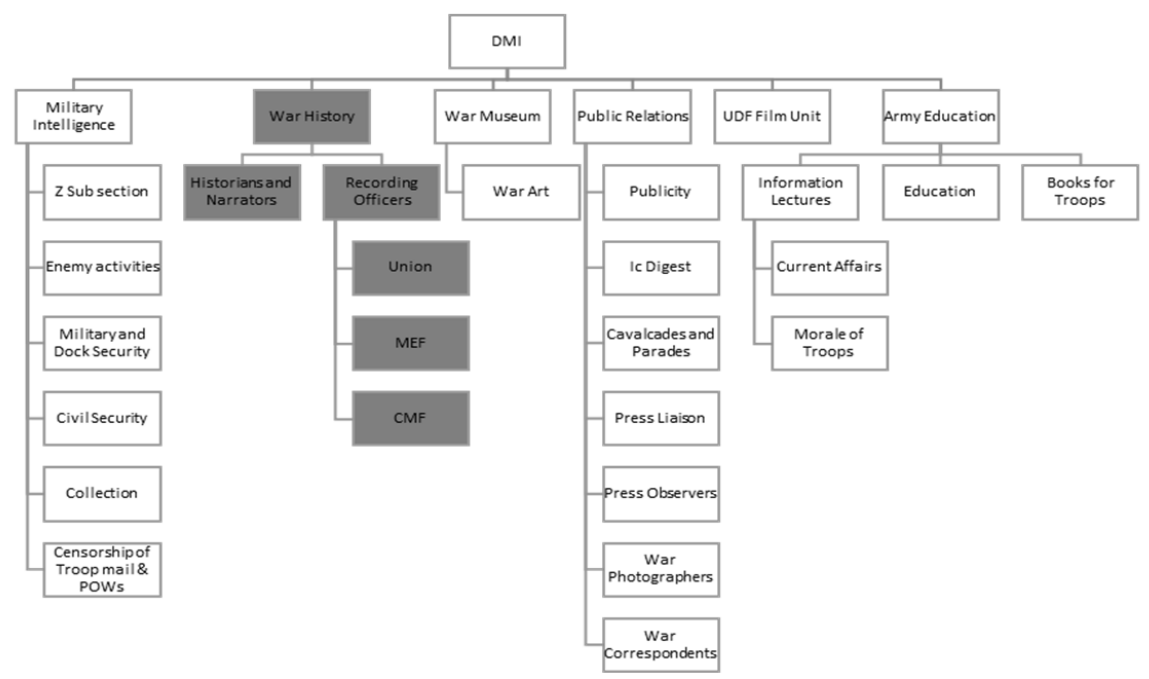

FIGURE 1: The Military Intelligence Directorate on 1 April 1945. The War History Section is shaded.

The Pretoria office housed a number of historians, narrators and archivists. Here, working under the broad supervision of a War Histories Advisory Committee, AgarHamilton and his team marshalled the war diaries and other records sent in by the recording officers in the field, wrote narratives, and kept the material for later work by historians. Agar-Hamilton envisaged a dual approach: 'a popular single-volume treatment aimed at a general readership [what he termed a 'people's history'] and a collection of more technical monographs written by and for those with expertise in various fields [which he termed 'military college' histories]'. ${ }^{17}$ In 1943, wanting to advance the process for the writing of a 'people's history', Smuts offered the job of editor-in-chief for a 'War History of South Africa' to Professor Eric Walker, a wellknown South African historian, who was then Vere Harmsworth Professor of Imperial and Naval History at Cambridge University. Walker, however, was only prepared to return to South Africa for a six-month period during which time he would 'map out the history and speak authoritatively on such things as lay-out, staff and so on, and get us over the chief of our hurdles. ${ }^{18}$ His illness delayed matters further. 
The War History Section lay within the DMI structure alongside the Military Intelligence Section (under Maj Charles Powell as DDMI), the War Museum, the Public Relations Section, the UDF Film Unit, and the Army Education Section (Maj Leo Marquard). There was a close relationship between these sections. Several of the information officers of the Army Education Section, Axelson included, had become recording officers, while the intelligence officers were the first-level clients for the war diaries and other documents the recording officers sent in from the theatres of war. But the relationship between War History, on the one hand, and Public Relations (PR) and the UDF Film Unit, on the other, was one of competition - for the limelight and scarce resources - and of personal dislike and even animosity between key individuals. These links and strains - explored further by Fankie Monama in Chapter 6 - would either assist or hinder Axelson in fulfilling his duties over the following eighteen months.

\section{WITH THE SIXTH DIVISION: PERSONALITIES, PROBLEMS}

Axelson joined the Division in February 1944 when it was still in Egypt. Commanded by Maj Gen WHE Poole, it proved to be something of a homecoming, because Axelson knew many of the people from his previous work as an education officer. To help him, he had a staff of two. He was, he tells us, fortunate to have Ivor Language, a journalist from Durban, as his driver/clerk. Agar-Hamilton, in a letter written in July 1944, summarised what appeared to him to be Language's qualifications:

His versatility amazes me, and I wonder whether he has ever the time to shave. He takes his meals, I assume, while walking, and sleeps for no more than four hours a day, standing up. I gather that he drives the truck, converts it into a dark room when required, and prints photographs, takes prisoners, marches them off to the cage, checks, packs and routes War Diaries, and occasionally does a little shorthand and typing - say 10000 words or so - by way of variety. Altogether he seems a most remarkable person. ${ }^{19}$

Axelson certainly agreed.

He also had a photographer to take $16 \mathrm{~mm}$ and $35 \mathrm{~mm}$ shots of Divisional activities. The man originally posted in this role was a Sergeant Boast. Cryptically, and rather kindly, Axelson noted that Boast left after he 'met with an accident on his first night in Italy'. ${ }^{20}$ There was, however, a more complex story. Boast had been something of a nuisance and was eventually returned to the Union when he injured himself. But the troubles had started before Axelson's arrival. Boast had not only removed photographic equipment to his digs, which had now to be returned, but had also run up debts in Pretoria before leaving for Egypt. Axelson had the unpleasant task of deducting $\delta^{3}$ per month from Boast's pay until the debts were settled. However, it did not stop there. 
The DMI and his principals at General Headquarters (GHQ) were unhappy with Boast's work and denied requests for further supplies of $16 \mathrm{~mm}$ film. The photographs taken were not only useless, but Boast had had a habit of wasting film, both still and movie. ${ }^{21}$ His replacement was Roger Madden. Handpicked by Agar-Hamilton, he joined Axelson in June 1944 and proved to be an excellent photographer. He not only had a gift for sniffing out and reaching the action, and for taking 'real' shots, but also proved to be a good companion. ${ }^{22}$

The Division's Recording Section seems to have been a happy outfit. The three men - Axelson, Madden, Language - got on well together. Axelson allowed a large degree of flexibility, affording his subordinates the freedom to get on with their work. On one occasion only does there appear to have been a brush, which involved 'the security people'. This concerned a leak of information to John Baird, a journalist with The Star. The matter came to official attention when, on 4 March 1944, there appeared in 'Stoep Talk', a column in The Star, a detailed account headed 'History while you Wait'. This not only described the work of the Recording Section in remarkable detail, but included the full names and previous careers of those involved. The Intelligence Branch (Ic) pointed out that Baird and Language had been old colleagues on The Daily News, and suggested that Language had been the source of the information. This had serious implications. This was not only unprofessional ('historians, like doctors, leave their works to speak for themselves', Agar-Hamilton admonished) and contrary to good discipline, but also prejudicial to the work as it raised suspicions that the section was in league with the press. ${ }^{23}$ Moreover, as Agar-Hamilton stressed, they could not risk a clash with the security people, on whom they depended in large part for the freedom to do their work. Language, if guilty, certainly made up for this early misdemeanour.

Axelson was also close to Agar-Hamilton, his principal at GHQ. They had known each other when in Pretoria and were on first name terms, as they sometimes were in unofficial correspondence with other officers, sometimes of different rank. AgarHamilton told Axelson in February 1944 that this

serve[d] to emphasize the fact that in our job rank is nothing. A man either knows his job and gets on with it, or he doesn't know, and no one, least of all a crowned mortal, can teach him. ${ }^{24}$

A Crown was officers' insignia: a major wore a crown on his epaulette, and the next three ranks combinations of crowns and pips. These 'crowned mortals' were therefore their immediate seniors in the line of command, many of whom, including Poole, a career soldier with an impeccable military record, would have opposed such informality. Some, perhaps not understanding prior professional and university connections, may have viewed this as a break in military discipline. And then some of these officers had to be convinced of the importance of recording work. The 'History while you Wait' article in The Star seemed to confirm the notion, perhaps 
widely held, that 'History' might be produced quickly and by people untrained in the historical method. Writing along these lines in February 1944, Agar-Hamilton expressed his frustration:

That is what makes me despair when people ring me up and say 'I'm sending Sapper so \& so or Sgt Blank to do our history. Just show him what you want done and he will do it.' Give me so \& so or Blank for three years and I might do something - provided, of course, he has the natural aptitude. ${ }^{25}$

The men of the Division, focused on warfighting, did not always understand the nature and often strategic implications of Axelson's duties. These they thought superfluous, a soft job, and his was a constant battle to obtain material of historical value. But, as we shall see, it did not stop there. He also faced bureaucratic obstacles and tribal jealousies. These emanated from Pretoria, sometimes in Italy, and manifested in different ways: in the difficulties faced in scrounging equipment, transport, cameras and reels of film, and in securing billets. The UDF Press section in Italy, on the other hand, seemed to have everything, or at least access to anything. While Axelson knew several of them, this created some unhappiness. They sometimes shared billets but there was a competitive undercurrent, the frequent brushes highlighting the differences between their occupations. ${ }^{26}$ For Axelson the equation was a simple one:

If I had transport - a jeep - I should be able to go over the battlefield with the company commander, and get the full story, illustrated with photographs, but no jeep, no story. No story, no history. ${ }^{27}$

\section{WORK AS HISTORICAL RECORDING OFFICER OF THE $6^{\text {TH }}$ SA ARMOURED DIVISION}

Axelson's responsibilities were threefold: (1) he had to ensure that every unit in the Division kept a war diary, as fully as possible, and that these were submitted to Divisional Headquarters every month; (2) he had to collect historical information and supplement the war diaries whenever possible with interviews; and (3) he had to 'make history for the Division'. ${ }^{28}$ These tasks might be captured as the raking in of historical material, and the working up of this material into a first history of the Division. However, as Jeffrey Grey has noted, 'collecting records was one thing; the quality of what was collected was quite another'. ${ }^{29}$

\section{Raking in historical material: war diaries, photographs, interviews, surveys}

\section{War Diaries}

Each unit in the Division had to maintain a war diary. This was essentially a current monthly report made by the respective commander and was comprised of a cover, 
a narrative and appendices. ${ }^{30}$ War diaries were submitted in duplicate to the recording officer, who forwarded them to Pretoria: one copy for analysis by military intelligence, for whom observations on the enemy, on health, and on morale were of immediate concern; the other for safekeeping by the War History Section. For this reason, strict instructions regarding their completion were issued and these were also printed on the inside cover of the War Diary folder. War diaries had to be 'accurate and complete' and include 'as much important information as possible'. The Narrative, supposedly written up daily, was to contain specific information, including the exact hour of occurrences, and was to be supplemented by, and be linked to, the appendices. ${ }^{31}$ The appendices were to 'add interest to the Diary' from an intelligence viewpoint and, at the same time, enrich 'the historical records of the UDF'. This enrichment of the record included photographs of unit activities, cuttings from local civilian newspapers, and unit magazines and newspapers. ${ }^{32}$

These war diaries, which in practice might be a couple of pages of hurried scribble, or a bulky folder, were Axelson's first concern. They presented several difficulties. Perhaps most were sent back regularly to the Divisional Headquarters, as per the instruction, but there were many instances where Axelson had to travel to regiments and battalions to find 'missing months'. This inevitably delayed onward transmission to Pretoria, which negated their effective, immediate utility. Moreover, possibly most diaries were incomplete. This may have been due to the exigencies of the war. For example, Lt-Col PCA Francis of the Carbineers explained that sitreps could not be included as 'everything [was] passed verbally over the phone'. ${ }^{33}$ The same story is told by the intelligence officer with the SSB ('most of their orders are verbal, that they are acted on immediately, and that no record of them is or can be kept ${ }^{34}$ ). Ignorance, or lack of awareness (for example, the intelligence officer of the SSB did not include an existing operational account of the battle at Celleno 'because he was not sure that we would be interested ${ }^{35}$ ), and personality (for example, Captain Ross, the acting Intelligence Officer at the Main Division, was 'not very enthusiastic about letting me have copies of the $\log ^{36}$ ) no doubt played their roles too. But Axelson had recourse to higher authority, in Pretoria and within the Division, and, at his request, the Division's G1 authorised the inclusion of 'O' and 'I' log sheets in the Division's war diary. ${ }^{37}$ This was a step forward.

Much of course depended on individual commanding officers. Axelson visited the Royal Natal Carbineers on one of his chivvying tours in late January 1945. The previous commanding officer had suffered severe strain and, having 'sought to dull the pain of losing so many of his men with alcohol' ${ }^{38}$, had (amongst other things) fallen horribly behind with his war diary before he was relieved of his duties at the end of October 1944. This left his successor, Colonel Francis, with the onerous task of 'building' these diaries, which were then many months in arrears. To his credit Francis not only brought the arrears smartly up to date, but also took steps to make 
them more readable, referring for example to places rather than to map references. ${ }^{39}$ The Non-Divisional units presented difficulties of a different nature. They were diverse and dispersed and many of these units did not render war diaries at all. This became evident when Trollip was tasked to write a narrative on the activities of these units, and special instructions were issued in January 1945 to chivvy them. ${ }^{40}$

Yet despite these problems, Axelson appears to have had good success. The relatively complete collection of war diaries, at least for the fighting units in the Italian campaign, at the Department of Defence Archives in Pretoria is testimony to the diligence of his little section.

\section{Photographs and the 'Public Relations' people}

Secondly, Axelson and his small team had to build a collection of photographs to supplement the war diaries and official record. Photographs are important to the military for a number of reasons. They are essential for the preparation of maps (46 Survey Company SAEC undertook this work for Operation Husky), ${ }^{41}$ they have their intelligence uses, and are indispensable for propaganda or public relations purposes. ${ }^{42}$ Additionally, photographs have historical value (they could be used as a visual diary that might be used later to recall events) and it was to this end that Axelson had been assigned a photographer. But all photographers shared the same difficulties on campaign. Photographic equipment and film were scarce. The cameras were relatively basic, they 'shook' easily and were difficult to focus. Some films, when developed, were completely blank. If developed in the field, the negatives were easily scratched. Sometimes film was sent to Cairo, later Rome, for development, and sometimes Axelson sent reels back to Pretoria. Film sent to Pretoria sometimes disappeared, forcing Axelson to use the DDMI as a postbox. ${ }^{43}$ Moreover, photographers had to travel, sometimes to 'unsafe places' to get the shots and, of course, due to the restrictions, not everything could be photographed. ${ }^{44}$

Some of these problems vexed Axelson little. Armed with his brief, he and Madden had easy access to the frontline. Moreover, Madden was a seasoned photographer, able to sniff out the action, cover the shots, and then develop the photographs in an improvised darkroom, sometimes on the back of their truck. Movement presented greater challenges. They were held up on packed roads, made worse in winter, forcing them to go off the beaten track in search of specific objectives, where possible. These varied from the Division's crossing of the Tiber, to the scouring of Kesselring's headquarters, where they found some maps that were sent to Historical Records. ${ }^{45}$ As a courtesy, when possible, the permission of the local South African commander was sought. At the end of June, for example, they found Lt Col Johnstone of the Pretoria Regiment, who 'replied that he most certainly had no objection to our watching his tanks and taking photographs. ${ }^{36}$ 
There are numerous references in Axelson's log to his moving about with a variety of people in tow. There were war correspondents, 'broadcast people' and 'PR people', as members of the Bureau of Information and the Public Relations Section were derisively known. Axelson had been in three theatres of war, with some continuity of role and purpose. He had also built up his connections and solidified earlier friendships, and he was thought to know where best to go and what to do. The war correspondents and bureau men, on the other hand, came and went, and some of them had been working on a high street only weeks before. ${ }^{47}$ Not unnaturally perhaps, they gravitated towards Axelson to pick up on stories or get a convenient glimpse of what was happening. ${ }^{48}$ But a number of difficulties would soon arise.

In the first instance, there was a vast difference in their work. In a sense, they were all there to document the war. However, the pressmen often flew in to cover a specific story, write a column with the right angle, add some sensation, and get the story into print. To illustrate, on 8 July the news came that the Division was unhappy with the write-up the war correspondents gave of Smuts's visit, with 'enemy tanks lurking a mile or so away'. ${ }^{49}$ This was manifestly untrue and the civilian press, it seems, generally disappointed. O'Connor, a SAPA correspondent in Italy in June 1944, for example, wrote a confused article on the action at Bagnoregio, ending with a sentence paraphrased by Agar-Hamilton: 'I'm blest if I know what it was all about, but anyhow it was a hell of a party. ${ }^{50}$ This was very different to what a recording officer had to do. Agar-Hamilton was blunt and to the point. In March 1944 he warned Axelson that if he went 'hobnobbing with correspondents' it might seem as if they were in league with the press, which would undermine the position and work of the recording officers. ${ }^{51}$ The lines were clearly drawn. No doubt the office politics in Pretoria had also played a role.

Axelson got on well at first with the press corps. Being trailed by pressmen was initially amusing rather than irritating. He and Madden would have a quiet laugh, shared in correspondence with Agar-Hamilton, about their foibles and apparent fear of being so close to the front. There are several amusing vignettes in the log. One morning Madden had to turn back because a Bureau cinematographer, who had cadged a lift, insisted they turn around ('After going a while the Bureau man remarked that it would be selfish if they went too far and got the vehicle hit, and so deprive the other war correspondents of transport; so they returned ${ }^{52}$ ). That same week the press corps packed up their camp and moved further south as 'some of the correspondents found it impossible to work amidst the noise of our mediums and the single telling enemy shell'. ${ }^{53}$ While, a week later, instead of covering the battle just ahead, 'the newlyarrived PR photographers preferred ... to fake action shots with a borrowed tank and phosphorous bombs'. The tank was set alight, and the fire extinguished, but two of the crew were badly burned. ${ }^{54}$ 
Although Axelson found some satisfaction in reporting such incidents (and he knew his log was circulated among the brass at General Headquarters), he explained somewhat smugly that he mentioned them 'not out of unkindness, but to emphasise the difference that exists between photographic side of Historical Recording, on the one hand, and, on the other, photography as visualised and practised by set-ups not concerned with historical truth'. ${ }^{55}$ The PR Unit - they produced about a thousand images per month - were criticised quite severely. ${ }^{56}$ Their photographs, of endless staff officers standing at saluting bases and units marching past, left Agar-Hamilton 'feeling a little bored, not to say satiated ... One would assume that 6 Division has done nothing else since it has been in the desert'. ${ }^{57}$ Sensitive to the South African public having 'no desire to be told that war is a nasty thing', the PR people fabricated and posed shots, which were largely confined 'to cooks and girls from the UDF Entertainment Units' ${ }^{58}$ They were interested in publicity and in images that had a reasonable chance of being released for publication. Herein lay the essential difference. Axelson wanted to place his photographer at the front to capture the action and images of the terrain over which the battles were fought. As Agar-Hamilton explained, "we want "record" photographs, with insistence on terrain and other technical details, with the specific instruction that they must be unposed' ${ }^{59}$ They wanted photographs of the grimmer side of war, including shots of enemy equipment. Egged on by AgarHamilton, Axelson wished to capture something of the war as it was. Yet he always had to proceed carefully. 'The PR set-up', as Agar-Hamilton cautioned, 'is the apple of DMI's eye, and any criticism is apt to be resented'. ${ }^{60}$ Publicity was critical in a country in which the war was a contentious subject and 'positive images' were imperative. ${ }^{61}$

Cooperation was important, however. Since 1943, the UDF Film Unit controlled all photographic stores for the UDF. But being short on skills and seasoned staff, Madden and Language could assist bureau photographers with the development of still photographs, sometimes providing the darkroom facilities and developer. ${ }^{62}$ Pooling resources was sometimes possible. The PR billets were mostly sited in prime locations: set against scenic slopes and alongside streams that offered leisure swimming. ${ }^{63}$ They had better transport (four new jeeps arrived for them on 9 July), which could be shared, and access to seemingly limitless resources, although, to Axelson's frustration, they also seemed to travel in Italy without darkroom materials. But things did not improve over the ensuing weeks and months.

Two things brought the matter periodically to the fore. First was the ongoing competition with the Public Relations Unit for scarce film and photographic equipment. Second, was criticism of PR work, which Agar-Hamilton at times succeeded in using to secure film and stores for his recording officers. Invariably, Madden did not disappoint. His sequences sent to Pretoria 'caused considerable interest' and Agar-Hamilton's praise was lavish: the captions 'were much more illuminating even in matters which were not censorable' and the quality of the photographs themselves was outstanding. ${ }^{64}$ 
While the DMI was happy too, the scarcity remained and Axelson was forced to scrounge. In this he had some success. His 'initiative, pertinacity, discretion, and all the rest $^{65}$ resulted in more than $4000 \mathrm{ft}$ of film in April, with the promise in May of two Contax cameras and $1500 \mathrm{ft}$ of $16 \mathrm{~mm}$ film per month. ${ }^{66}$ The promises invariably fell through, leaving Agar-Hamilton to advise that Axelson 'keep on as long as you can'. ${ }^{67}$ On 12 July the Bureau raised the stakes. They wanted Madden to be seconded to the Bureau. In the end, a middle way was found. Madden would remain with Axelson, but would be available to the Bureau and fully supplied by them with all the photographic material he needed. ${ }^{68}$ This was perhaps the best Axelson might have hoped for. Clayton, the head of the PR photographic unit in Italy, explained matters in no uncertain terms: he was under no obligation to cooperate with Axelson as he was there 'for propaganda purposes only'. He was not interested in photographing 'forward stuff' and, as the public did not want to see the ugly side of the war, he would focus on 'reconstructing' ${ }^{69}$

It is indeed unfortunate that there was no proper photographic unit to serve the War History Section. There is no doubt that the Division's Recording Section might have achieved much more had they had adequate equipment, transport and more staff. But the war meant other priorities were in place. Notwithstanding, the 'action shots' and the collection of photographs Axelson took of 'the classic air journey up Italy' proved to be a great boon to modern researchers. ${ }^{70}$

\section{Personal narratives}

Thirdly, Axelson had to supplement the war diaries, where this was possible, with interviews, which often took the form of a personal narrative, or they were later developed into personal narratives. This aspect of Axelson's work had a different rhythm. Whereas the war diaries were to be submitted on a monthly basis and Madden's camera followed the action, the interviews followed as soon as possible after the end of battles and actions. In early 1944, as Axelson arrived in Italy, a bundle of thirtyfour narratives, dealing with the campaigns in North Africa and Madagascar, arrived in Pretoria. These were mostly personal narratives. Their value was acknowledged by the Deputy Chief of Staff, Brig Gen HS Wakefield, in a letter to Poole and the advice given the commander of the $6^{\text {th }}$ Armoured Division is worth quoting at length:

Documents of this sort are of exceptional value as amplifying and interpreting the official records, and it is hoped that as many as possible will be secured and forwarded to the Union. Personal narratives embodying, as far as possible, the language and ideas of the narrator would be welcomed, particularly in respect of units which were detached from the South African higher formations and came under command of British formations, or of smaller detachments which were attached to British units. ${ }^{71}$ 
Agar-Hamilton probably wrote this letter for Wakefield's signature. Axelson saw it the original is among his personal papers - and from it he took his prompt. The argument regarding the importance of such narratives, and that 'as many as possible will be secured and forwarded to the Union', strengthened his arm. With the folding of the Gustav Line and the German retreat, Agar-Hamilton advised that his chief task was now 'to see that things are wound up neatly, and that all the promised stories and narratives duly come in'. ${ }^{72}$ In June they found Lt Col 'Papa' Brits, who, in one of their first interviews, gave a statement on the action at Celleno to supplement the SSB war diary. ${ }^{73}$ Other interviews followed. Sometimes interviewees were surprised to see Axelson and his team there: in late June 1944, on the road to Chiusi, Lt Col Jack Bester (Regiment De la Rey) 'expressed a certain amount of surprise at seeing us. He said that this area had not yet been cleared'. ${ }^{74}$ On occasion Axelson and Madden joined a forward patrol. The following extract from 30 June, for example, illustrates his proximity to the front. Axelson narrates:

There ambled up the road past us a yellow-shirted, maroon-trousered blonde and bespectacled Italian youth. Madden remarked 'It is surely dangerous to let these people wander about like this? They may be carrying information to the enemy.' It certainly did seem dangerous. It turned out to be so, but for him, not for us. Over on the left, through the trees, I could just make out the hunch of harvesters. After the first shot they had continued unconcernedly on, but now they were really flustered, and the women ran first this way, then that. They dropped their sickles and scythes, and herded together under a tree, looking anxiously up towards us.... there was a burst of Spandau fire ... Ten yards from us, in the roadway, the youth lay groaning. ${ }^{75}$

These experiences were important for Axelson and his shaping as a person and military historian. The war in Italy was being fought amongst the people. ${ }^{76} \mathrm{He}$ not only came to appreciate the method of clearing areas of enemy rear-guard troops, but gained a special appreciation for the fighting spirit of the men and for the invaluable contribution made by Italian partisans. He also came to appreciate the difficulty of writing notes later. He and Madden, when comparing their accounts later, found that they 'were confused as to the details and sequences and times' and could now 'appreciate the difficulty experienced by members of the Division when they make statements to the Historical Recording Section'. ${ }^{77}$ Memory is certainly a highly subjective construction of experience.

But working as close to the battlefront as possible and holding the first interviews could take them only so far. Axelson also had to write up these narrations in the vernacular, the language of the ordinary soldier, and embody 'the ideas of the narrator'. The narratives had to be genuine, unadulterated and recorded without embellishment. For this reason, Agar-Hamilton advised, that while the Press may offer ease of transport, Axelson should not visit units 'in their train, or as one of their 
hangers-on, so to speak.' While 'men like ... to talk about themselves ... most of them shut up when the Press appears on the scene, partly because they have been trained in security, and partly because they don't want to be made to look fools in the columns of a newspaper'. For this reason, Axelson was advised to conduct interviews on his own and, if present while a journalist was gathering material, to keep 'keep tactfully to one side'. Clarifying to all the essential difference between the work of historians and propagandists would ease any disquiet among the men and assuage security concerns among higher-ranking officers, including Colonel Hartshorn, the officer responsible for security on Theron's staff. ${ }^{78}$

The 'gap' in this material was perhaps most obvious where no South African formations were engaged, but only individual South African units. This might result in little to no coverage in the South African press and no war diaries which could be forwarded to the higher headquarters of other Commonwealth or American formations. The Rhodesian troops serving in South African units and formations suffered similar invisibility. This Axelson could address more readily: he kept in mind matters likely to have a Rhodesian interest, arranged to have photographs taken, and recorded the personal narratives. This he did as well as pick up back material. ${ }^{79}$

These short personal wartime narratives, hunted down and captured by Axelson, may have been the germ for a number of published accounts that would appear after the war. Such accounts have a particular value. They may be unvarnished and personal and, not having passed through censorship, they may also be more critical of senior officers and politicians. As discussed in Chapter 1, they may also sometimes address taboo or off-limits subjects such as morale, fear, discipline, combat fatigue, desertion, expressions of sexuality, use of alcohol, rape, looting, atrocities. The historical surveys, or regimental histories, written at unit level were quite different.

\section{Historical Surveys and Regimental History}

One has to understand regimental history for what it is. Frequently dismissed as being sanitised, parochial and concerned with ephemeral minutiae, they nevertheless have a specific place. Regularly compiled after wars, regimental histories are memorials to fallen comrades, for those of the battalion that did not return. For this reason, such histories often include lists of fallen and details of casualties. Equally important, regimental history is written by the survivors as an explanation to the families of the regiment, of what their men had endured and suffered. This touches on the notion that one cannot write the history if one was not there. ${ }^{80}$ For this reason, while regimental histories steer away from distasteful events - of drunkenness, prostitution, looting they are equally a response to other histories. ${ }^{81}$

As a stimulus in this process, GHQ instructed the Historical Section to coordinate the writing of historical surveys covering the work of the South African forces in the 
Mediterranean theatre. Commanding officers and heads of branches were asked to submit a survey covering the history of their units and sections. Detailed directions were thought to be impracticable and undesirable: each unit would be allowed to 'tackle the job' given only a broad remit. The object was 'historical' as well as 'utilitarian':

It is necessary to know 'what happened' for the administrative aspect of the official history of the UDF; it is also necessary to know 'what happened' and 'why', because the future organisation and administration of the UDF will, to a large extent, be determined by the experience of this war. The sources at present available, War Diaries and office files, are not, by themselves, adequate to meet these requirements. ${ }^{82}$

The instruction continued:

The Survey should, then, explain the work of the Section: the purpose for which it was formed, how it was proposed to realise that purpose, and how, in fact, it functioned. In a phrase, Policy, Organisation and Administration. Special attention should be paid to changes and alterations: were these the result of altered circumstances, or did experience indicate that though conditions remained the same, the original set-up was unsatisfactory and in need of modification? Where relevant, relations with other Headquarters (British or American), GHQ Pretoria and field formations and units should be discussed. Constructive criticism and suggestions for improvement, with reasons and examples, will be very valuable. ${ }^{83}$

This was operational research, with a focus on 'lessons learned'. Officers best qualified to do so had to be identified and instructed to write these surveys, and their names sent to the Historical Section by 10 June 1945. They would have full access to information held by the Historical Section at the UDF Administrative Headquarters. The instruction was issued on 7 June 1945 and, it was hoped, all units would complete their reports and submit them to the Historical Section by 15 July 1945. The target date was, of course, entirely unrealistic and the results was varied: some units in a frenzied scramble produced judicious accounts; others acted only in measured bureaucratic compliance.

The historical survey of 1(SA) L of C Field Security Section (FSS) might be used as an example. ${ }^{84}$ This survey is a tightly-typed, 80-page, 4 200-word narrative, with appendices, covering the war from when the first field security section was created in 1940. The move to Italy had brought a number of changes, including a focus on civilian rather than military security, and their investigations covered sabotage, illicit arms trafficking, black marketeering, and the detention and interrogation of Italians denounced as having exposed escaped Allied POWs after the capitulation of Italy. As a non-divisional unit attached to a British headquarters, the FSS was isolated and ran the risk of becoming invisible. But fate would intervene. Axelson and his Historical Recording Section shared billets with an FSS post in Castelnuovo in July $1944 .{ }^{85}$ 
In the evenings the officers spoke of their work and Axelson gained access to the weekly field security reports, including some details of the robberies, rapes and murders committed along the Divisional axis. ${ }^{86} \mathrm{He}$ also interviewed other officials he met regarding the relations between South African troops and the local inhabitants. ${ }^{87}$ Importantly for this unit, however, the serendipitous friendship of the recording officer may have resulted in a complete set of detailed war diaries and a reasonable historical survey.

Axelson influenced the writing of corps and regimental history in other ways too. $\mathrm{He}$ became a sounding board for several unit commanders, who either sought to 'correct' the history that was being projected, or gain advice on the writing of a post-war history. Two instances will suffice. On 6 September 1944 Axelson visited the tactical headquarters of the Imperial light Horse. Lt Col R Reeves-Moore, who was 'very anxious that the history of his battalion should be written properly', wanted to see him. The Army Commander had recently 'congratulated the South Africans on their advance from Rome to Florence, but added that the South Africans' eventual entrance into Florence was very largely due to New Zealanders.' Reeves-Moore strongly disagreed and, explaining at great length the course of events as he saw them, wanted the history of the battalion written 'to prove that view wrong'. He seemingly wanted Axelson for the job, but added that he was 'prepared to write it himself' ${ }^{88}$ Some weeks later Axelson, constantly in need of transport, cadged a lift with Colonel CCP Anning, the Assistant Director Medical Services (ADMS) attached to the Division. Anning ran a tight organisation and the relatively light losses suffered by the Division speak to the diligence and efficiency of his field ambulances, dressing stations and casualty clearing posts despite the taxing operational environment. The Italian campaign created a new disease environment and methods had to be adapted. ${ }^{89}$ Anning took the divisional recording officer on a tour that included the advanced dressing station of 10 Field Ambulance, and several casualty clearing posts. The men and women of the SAMC were building up a proud record and Anning wanted 'the medical history of the UDF' written up. ${ }^{90}$ This Anning seemingly did himself in the immediate post-war years.

Importantly, however, the short historical surveys, written under pressure in June and July 1945, may have been the germ for a number of regimental, unit and squadron histories published after 1945. ${ }^{91}$ Several of these are brief and unvarnished, and carry the hallmarks of official history. Jeffrey's The $8^{\text {th }}$ Field Squadron, for example, appeared in 1946. It includes a route map, a roll of honour, lists of honours and awards, a number of personal photographs, and cartoons by a fellow sapper, who died tragically at the end of the war. One cannot say with any certainty exactly how important the June 7 instruction was in giving impetus to this spate of post-war history writing, or to what extent these books were expansions of these historical surveys. However, it would seem as if a hurried official process gave impetus to some of the regimental histories that followed. 


\section{Writing the first history of the Division}

Axelson also personally contributed a substantial amount of writing on the history of the Division. He did this at three levels: his draft narrative of the division's history, his $\log$ of the activities of his recording section, and his vast correspondence, which may be assembled by the historian from material lying primarily in Cape Town and Pretoria. The last, his regular letters, were detailed, arrived punctually, and were often circulated at GHQ. They were, Agar-Hamilton extolled, 'interesting and useful' as the war diaries invariably arrived late and even Axelson's reports and papers, 'after being pored over by various authorities at Division and Base', were also 'apt to be considerably delayed'. ${ }^{92}$ His letter written from Acquafondata, for example, created considerable interest and Malherbe sent it to Wakefield:'It was the first real news about the Div which had reached DHQ (GHQ) and went down well'. ${ }^{93}$

\section{First drafts: a 'Divisional' history}

In 'making history for the Division', Axelson wrote the first drafts that might be used as a guide for later historians. He was a professional historian, but recognised that military history was its own distinctive field and so sought the counsel of seasoned counterparts. In particular Major Eric Linklater, the British official historian, became something of a mentor. Linklater visited the Division on several occasions and imparted much wisdom. He had written The Defence of Calais (1941) and was contracted to write a history of the British Army in Italy, of which the South African Division was then part. As Axelson later noted, 'it was natural for me to seek his advice' ${ }^{94}$ When writing Defence of Calais, Linklater's greatest problem had been a lack of material. As he explained:

There were a few odd survivors only. I had to interview them and get information from them. I had to start with a point at a particular time, and build up information about a widening area about that point, through an increasing span of time. ${ }^{95}$

Axelson he advised that would have the opposite problem, the difficulties associated with ample material. On this, Linklater gave all kinds of advice. In writing the division's historical narrative, he advised that Axelson:

write a preliminary narrative, then examine war diaries and re-write your narrative. Examine 'I' reports, sitreps, etc., and re-write again. Embody such personal narratives as may be of use, and re-write finally. ${ }^{96}$

This phased approach, of adding material in successive steps from the war diaries, the intelligence and other reports, and personal narratives, might assist in dealing with the amount of material that would become available. However, it was equally important that, while writing, care should be taken to avoid bias, perhaps towards units with 
which the Historical Officer was staying. For this reason Linklater counselled that there was a need for 'as broad as possible a picture is necessary, but a little local colour and atmosphere are admittedly indispensable. ${ }^{97}$

Linklater also spoke to Axelson about the use of interviews. These were deemed to be essential. But while interviews might be used to provide the local colour and atmosphere, he advised, it was 'usually useless to ask anybody after an action for a general account of what he has done'. Instead the recording officer should 'ask him questions about what he was doing at a particular place at a particular time'. ${ }^{88}$ Only such targeted questioning would produce useful information. Likewise, the interviews had to cut across all ranks. Generals were important but, Linklater reasoned, 'a general cannot get out of his head his intentions'. ${ }^{99}$ Conversely, great reliance could not be placed on the ordinary soldier at the other end of the rank spectrum, for his view was necessarily narrow and often equally exaggerated. Here Axelson and Linklater agreed.

However, where they possibly disagreed was in terms of purpose. For some historical officers, accuracy was not the holy grail. Good publicity was the primary objective: the raising of the profile of the formation, and so of morale at the front and at home. The historian of 13 Corps, a Lt Col Kittoe, who was working on a short history of the Allied advance from Sicily to the Alps, told Axelson in September 1944 that he planned 'this history to be accurate and truthful.' He was after all, Axelson reasoned, a professional historian, but then Kittoe also did 'not intend ... to blacken characters.' He would 'slur over the bad, play up the good'. ${ }^{100}$ That, for Kittoe, was the task of the official historian. These were wartime narratives, having a specific purpose, and a more critical history could be written after the war. The South African recording officer could not fully subscribe to this view.

Axelson's monthly reports are in the custody of the Department of Defence Archives in Pretoria. These provide a window onto him personally and his small team, and their work. Axelson wrote the divisional history at an enviable rate of 30000 words per month. ${ }^{101}$ Taking Linklater's cue, he used official documents, trawled the war diaries as they came in, and incorporated material from interviews and personal narratives where he could, and, finally, there were his own observations as an embedded historian. The result is a lively narrative of remarkable context and depth. It was essential, he noted in his $\log$ on 12 July 1944, 'to view the whole Italian battlefront from sea to sea [in order] to view the South African contribution in correct perspective'. ${ }^{102}$

The narrative was of exceptional quality, despite being typed up sometimes on the bonnet of Axelson's truck. It also stood in sharp contrast to the official Bureau news, which, as Agar-Hamilton lamented in May 1944, 'was an incredibly dull affair: with the exception of one point - the local nickname for British troops - anyone of us might have written it sitting comfortably at GHQ'. 'There wasn't', he continued, 
'a scrap of human interest, let alone a single "significant" fact, or picturesque one for that matter'. ${ }^{103}$ But this is not to say that Axelson's endeavours were praised by all. When he returned to camp on 21 July 1944, he found Linklater waiting for him. Linklater had just received the 'most disturbing news' of Axelson's recording work. There were complaints at higher headquarters that Axelson was 'looking at the war from the wrong end of the telescope'. The complainants, probably 'crowned mortals' on Poole's staff, argued that 'they wanted to see it from forward patrols', instead of, as Linklater affirmed, 'from a proper perspective'. ${ }^{104}$ Collyer had encountered the same difficulties when writing his history of the German South West campaign in 1936, of the strategy of the campaign versus the work of the different units. ${ }^{105}$ However, to be fair, the complaint seems somewhat unwarranted for that May; Axelson had in fact written a narrative of a night patrol, which he had penned in granulated detail. ${ }^{106}$ Notwithstanding, it was enough to cause him considerable humiliation and this seemingly depressed him. ${ }^{107}$

The first instalment of his running record covered the division's history from concentration and preparation (Chapter 1) to the fall of Florence (Chapter 9). He sent this to Agar-Hamilton on 30 August 1944, some weeks after receiving the first complaints. Unrepentant he wrote: 'Here is a brief account intending to act as a kind of a sort of a guide to the swill that is now deluging in on you'. ${ }^{108}$ He praised Language for the clerical work he had done and promised to bring amendments and make additions later, after the staff at divisional headquarters had seen it. Having adopted Linklater's incremental approach, he noted in the introduction that:

The account is based on incomplete and inadequate sources. Numbers of war diaries for Jun and Jul are still outstanding, and there are no operational reports yet available for examination. The account is accordingly only a preliminary, provisional sketch. It contains opinions, not judgements, and it is more a chronology than a history. It is intended as a guide only for members of the Historical Recording Section. ${ }^{109}$

Axelson may have been self-effacing and certainly placed the normal caveats in terms of the provisional nature of the manuscript, the need to do further research, and that the circulation should be restricted. The word 'provisional' was even included in the subtitle. As far as the military history of the period goes, the manuscript is readable, the military terms and abbreviations are explained, and the focus moves down at times to the tactical level. But, at the same time, the necessary context, width and depth - to allude to Michael Howard - are provided. He explains the 'bewilderingly different' situation that the South Africans faced in Italy, the nature and impact of the terrain, and the supply problems that were experienced. He did not shy away from irksome matters. Although it remained perhaps, in the minds of some, a distant anonymous view, with relatively few names mentioned, Agar-Hamilton was again lavish in his praises. It was he said, 'a thoroughly good piece of work', one written under 'very great 
difficulties and impossible conditions'. It did Axelson credit and required no apology. Moreover, as he noted, the Operations Section made a copy for their use, despite Agar-Hamilton impressing upon them that it was 'one of our private documents and in no way a final verdict'. ${ }^{110}$

This first instalment numbered 93 typed pages and included a number of 'factors [that] had contributed to the success of the Division's advance'. These factors almost speak to military-style 'lessons': the importance of training; the building of experience and troop resilience; the role of armour, reconnaissance and artillery; the importance of cooperation between infantry and armour, and air support. He praised especially the junior leadership, but criticised the staff at divisional headquarters saying few were battle-hardened at the start of the campaign. He also highlighted the role played by the two external factors. These were the Italian partisans and the flanking formations. In the first case, the assistance 'was unseen and indirect, but by their raids on the enemy L of C and supply dumps they kept, according to captured enemy documents, a considerable enemy force in the rear which would otherwise have been used against the Allies in the line'. The second, the flanking formations, 'time after time ... extricated [the Division] from awkward predicaments'. ${ }^{111}$ Such praise for the British, French and New Zealanders was sometimes a bitter pill.

The second instalment was submitted in March 1945. It comprised a further 146 pages, in addition to a chronology and index of place names and units, and covered the division's history from joining the US Fifth Army in August 1944 (Chapter 1) to the end of the winter in February 1945 (Chapter 16). Based primarily on war diaries, intelligence summaries and sitreps, it too was intended to be 'an interim guide for use by historical sections only' until Axelson could supplement it with personal narratives and other source material. As he explained in the preface, he had not had full access to all of the documentation necessary for its compilation, resulting in significant gaps and possible errors. In particular, he required more information concerning 'higher policy, flanking formations, and non-South African units under command of 6 SA Armd Div.' For this reason it was only provisional. ${ }^{112}$ But, as we shall see, notwithstanding these caveats his narrative created an immediate controversy.

\section{The 'log': Axelson's own 'personal narrative'}

Alongside this Axelson produced his 'log' of the activities of his Recording Section. As he noted in the preface to Taranto to the Alps, this was a true diary. Each evening, after reaching camp, he noted the foremost events of the day and the impressions he had gained.Approximately every fortnight, as the situation allowed, he had dictated extracts to Language, who, 'armed with a typewriter', hammered out the copy. Comments made by Madden, who was invariably nearby, and Language, as he looked up from his machine, were included on occasion. Two copies were produced: one for Axelson, 
the other for despatch to GHQ, Pretoria. ${ }^{113}$ This document is a fine supplement to his 'running record of the activities of the Division'.

The 'log', written without affectation, was an immediate success. It not only provided entertainment at GHQ - 'its usual quota of official delight' - but was also the first real news of the division. ${ }^{114}$ Interpolated with charming vignettes, it provides a lively image that captures the life of the Division and presents a window through which to study a range of conditions, from tensions at the 'sharp end', and allied rivalry, to the more comfortable living conditions in the rear and the interactions with the Italian people. Axelson drove around the countryside, sometimes drawing fire. He spoke to men in all allied uniforms, co-operated with the historical officers of other formations and picnicked with the local nobility. Its value was seen immediately. Extracts were sent to the SA Military College for officer tuition in late 1944. Agar-Hamilton described the $\log$ as 'all first-rate stuff'. His only regret was 'that for the present ... its circulation must be limited by security considerations' ${ }^{115}$ Months later, the log was still thought to be 'the only authentic account of the Division which reach[ed] GHQ'. ${ }^{116}$

After the war Axelson produced his own personal narrative - Taranto to the Alps - which was essentially the log recrafted, his own story written in memoir form. Comprising eight chapters and a few hundred typed pages, it includes extracts from a number of letters he received whilst in Italy. This may be seen in some ways as a presentation of evidence and a vindication of what he had accomplished. Leycester Walton, who had served in Italy and had known Axelson, made the commendable decision to publish this in 2001 as A Year in Italy.

\section{THE RESPONSE TO AXELSON'S WORK}

There are essentially three audiences for military history. In the first instance there is the general public that reads largely for pleasure. This readership wants a good story, one of bravery, persistence in adversity, and resilience in overcoming seemingly insurmountable odds. Such narratives might earn support and respect for the armed forces and, more widely, meet goals in nation-building. The story, if written by an official war historian, is often sanitised. The second is the academic audience, which is comprised of scholars, most of whom are university-trained and possibly university-based. This readership is critical and engages with the past in order to gain a better understanding of its complexity and significance in a wider context. The third is the military audience. Uncritical in the scholarly sense, this readership focuses on professional military development. Battle-oriented, theirs is the quest for objective knowledge and the distillation of easily-understood 'lessons', which might be objectively used to improve performance. For them there are definite, hard, military outcomes. If not, the effort in writing history is in vain. ${ }^{117}$ 
The responses to Axelson's work illustrates nicely aspects of these three readerships. Axelson had been handpicked. Agar-Hamilton first met him when on a field trip to Kwaaihoek and the site of a Diaz Cross. Axelson was there to give the lecture. He gave, Agar-Hamilton recounted years later, 'a graphic account of the detective work which led up to the identification of the site and the appalling labour of the search for the fragments of the monument itself'. ${ }^{118}$ The older man was clearly impressed and, when the opportunity presented itself, he had opened the position at War History. Axelson was in every sense an official historian. He volunteered for wartime service, worked in uniform and reported to military lines of command. But he was also university-trained, had joined the UDF from a full-time university positon, enjoyed the cut-and-thrust of intellectual banter, and he had brought with him a critical eye and an air of informality. While in official employ, such professional historians can be useful. They might be used to document the war and build, if not subscribe to, an official narrative. Linklater and Starr wrote and had published their respective official histories of the Italian campaign. Axelson wrote and redrafted his history several times, but this was never published.

Axelson's draft history was not well received by the division's senior officers. The troubles seem to have started soon after he joined the Division. The work of the recording officers, and of the war historians in the field, had grown steadily in standing and importance. Some may have become emboldened in terms of raking in the material and also in drafting the first narratives. Agar-Hamilton had encouraged this. He wrote to Axelson in May 1944 stating that 'the historian may now step out of his obscurity and begin to pass judgement'. ${ }^{119}$ Moreover, Axelson's 'log' of the Division's activities came to provide an alternative narrative, albeit at first to the very limited circle at GHQ, to the Bureau of Information's rose-coloured coverage of the war. ${ }^{120}$ Steadily, through the course of 1944 and 1945, Axelson would gain a reputation as narrator and historian.

But the frontline soldiers did not always see things this way. Writing on behalf of Poole in June 1945, Colonel Maggs wrote to Wakefield that Axelson's 'report' (the word itself is significant) was written by somebody 'lacking in military background [and therefore it] had no military value'. ${ }^{121}$ He indicated that Poole had realised this too late in the campaign to make a change. Poole wanted an old-style, official history with hard, practical value. Moreover, he disapproved of Axelson's gathering interviews and statements from all ranks. At least two senior officers complained that the narrative was not authoritative and demanded that it be rewritten. Various senior officers argued that the names of commanders and other senior officers be included wherever possible, 'to give more colour to the narrative'. ${ }^{22}$ But there were others issues. Fighting soldiers do not respect men in uniform filling 'soft jobs'. The men of the Division had trained together for a year before moving to Italy, while Axelson joined them shortly before that deployment. He was still, in this sense at least, an outsider. 
And then there was the notion that the soldiers did the fighting, and the dying, but one of these 'soft jobs' would sound off on the meaning of their sacrifice. As one Canadian veteran of the Great War noted to another: 'Soldiers make wars, but historians make the history of them'. ${ }^{123}$ The post-war historian, from the viewpoint of at least some of these officers, was in a position to ruminate at leisure and write of success and failure, and quite possibly apportion blame. Reputation was undoubtedly a major animus. In short, Poole, like his senior staffers, did not like Axelson's academic brand and he would not have him write his division's history.

Other steps would be taken. In June 1945 Poole set up a committee, chaired by a staff officer, to 'guide and assist' a Lt Davis 'in the compilation of the Division's history'. ${ }^{124}$ Some of his regimental commanders seemingly followed suit for their regimental histories. Some years later, after an initial probe, Axelson was excluded from writing a history of the Pretoria Regiment and its role in the Second World War. Enquiring on his behalf, Agar-Hamilton was 'told, most politely [by Colonel Johnstone] to mind [his] own business'. ${ }^{125}$ Put in his place, Agar-Hamilton rang off, leaving the regimental history to Johnstone and a committee of 'various officers'. Needless to say, as is so often the case with committee-directed history, no history of the $6^{\text {th }}$ SA Armoured Division appeared and neither has a history of the Pretoria Regiment.

This was a blow to Axelson and his sense of self as historian. After the war he joined Agar-Hamilton, and a number of fellow recording officers, in the Union War Histories Section in the Office of the Prime Minister. There he served briefly as Assistant Editor (Military) and then Chief Narrator. But, perhaps feeling the reputational blow, he left for Salisbury, Rhodesia, where archival work brought him back to his pursuit of the Portuguese in Africa. Nonetheless he returned to War Histories in November 1951. Malherbe, the former DMI and then Rector of the University of Natal, wrote a warm letter saying he had 'felt it was a pity that [Axelson] should have left that set-up at all, as [he] was probably the most experienced war historian we had in the field'. ${ }^{126}$ Agar-Hamilton welcomed him back too. He had not only missed an old friend, but wanted a sound colleague to work on a history of the SAAF in North Africa: the Australians, Agar-Hamilton told Axelson, had been treating the South African war effort 'with lordly disdain' and were asking for narratives of the Desert air war. ${ }^{127}$ Axelson produced a number of narrative histories over the following years, including one on 'The German Submarine offensive in South African waters'. ${ }^{128}$ But change was afoot. The Union War Histories, for so long under attack by the Nationalist government, would close in 1961 and its staff disperse to history departments, research institutes and archives repositories. ${ }^{129}$ Ahead of the wave, Axelson returned to his original interest in the history of Portugal in Africa and, in 1955, accepted a position in the Ernest Oppenheimer Institute for Portuguese Studies at the University of the Witwatersrand. He moved down to the University of Cape Town in 1962 as the King George V chair and head 
of the History Department there. ${ }^{130}$ A number of publications - all on Portuguese explorers and the role of Portugal in Africa - appeared. ${ }^{131}$

Axelson was certainly prolific. More than anyone else, he shaped the 'memory regime' - the historical record and history writing - of South Africa's campaign in Italy. Bourhill and Pretorius agree that 'to a large extent, the history of this campaign originates from the work of the historical recording section of the $6^{\text {th }}$ South African Armoured Division'. ${ }^{132}$ His contribution has almost no equal in South Africa, not for any war or any campaign. Even if unacknowledged in some military circles, Axelson had built a strong professional reputation as an historian working in the broad field of military history. He not only attracted postgraduates working on military topics to the University of Cape Town, but his MA students included a director of the Military Historical and Archival Service (the forerunner of the present Department of Defence Archives) as well as a dean of the Faculty of Military Sciences at the Military Academy, Saldanha. ${ }^{133}$ As far as can be ascertained, no student of his worked on the Italian campaign. This was left perhaps respectfully to Axelson himself, who, during his later years, recrafted a campaign history. This too was never published.

A history of the $6^{\text {th }}$ Division and of the Italian campaign finally appeared in 1975 . This was the fifth volume in Purnell's South African Forces in World War II series. Its author, Colonel Neil Orpen, was a journalist by profession, but one with the requisite military credentials. ${ }^{134}$ The history of the war had become increasingly problematic after the closure of the Union War Histories. However, Agar-Hamilton's advice, that a university be approached to sponsor the project and that Axelson be involved, was ignored. The University of the Witwatersrand, where Axelson was at the time, was willing to 'release' him for the work but, unable to move Lt Gen George Brink on the matter, AgarHamilton refused to join a reconstituted advisory committee. Although Brink managed to 'shore up' an advisory committee, and sponsorships were secured, 'the twin tasks of research and writing' remained problematic. ${ }^{135}$ Veterans were approached, none of whom had had the benefit of an historical education, and their writing is without exception uncritical, event-oriented and fact-packed. While Orpen quite clearly used tranches of Union War History documentation, including the material generated by Axelson, he acknowledges neither Axelson's narratives nor the work of the historical recording section in building the historical record for the Italian campaign. ${ }^{136}$

Finally, reference must be made to the three works on the Division that have appeared since 1975. The first is the doctoral dissertation delivered by Johannes Bruwer at the Rand Afrikaans University (University of Johannesburg) in November 1989. Adopting a very traditional approach, this is based on an extensive reading of the war diaries, supplemented by the Divisional Documents and the manuscripts in the Union War Histories collection. Bruwer seemingly went to some trouble to interview men who had served with the Division. However, while use was made of Axelson's materials, 
there is no mention of him or the ground-breaking work he had done. ${ }^{137}$ The second, Jack Kros's War in Italy, adds little to the historiography. However, while Axelson is not mentioned at all, the title of his memoir - Taranto to the Alps - is used as the subtitle for this book. ${ }^{138}$ Of course, this may be entirely coincidental. Importantly, James Bourhill brought a number of exciting developments in Come back to Portofino. ${ }^{139}$ Developed as a doctoral dissertation at the University of Pretoria, he used his own father and one or two other Springboks, who had left documentary legacies, as lenses through which to study the everyday life of the more than ten thousand men of the Division. The result is a good introduction to the division and to the wider South African campaign in Italy. Axelson, and his role as divisional recording officer, is referenced throughout and his spirit is felt: Bourhill addresses divisional successes and setbacks, victories and indecencies, and the cruelty of a total war, but also magnanimity and the triumph of human spirit. Still, surprisingly, Bourhill did not use the Axelson Papers, but depended solely in this instance on the material in the Department of Defence Archives.

\section{CONCLUSION}

The South African supreme command, breaking the pattern of the Great War, deployed military historians with the operational forces during the Second World War. Eric Axelson joined the $6^{\text {th }}$ SA Armoured Division in February 1944, as its Historical Recording Officer. Allotted a small staff, he had to ensure that each unit in the Division maintain, and submit to Divisional Headquarters on a monthly basis, a credible war diary. This Axelson supplemented with 'a running record of the activities of the Division', including, wherever possible, interviews with participants. He also kept a log of activities of his Recording Section, which, as he noted in the preface, was a true diary, containing his daily jottings and the casual comments of his driver as well as those of his photographer.

But several high-ranking officers did not like Axelson's brand of history. Axelson wrote his history as he saw it. In many respects, his history was the opposite of the more traditional, institutionalised type: his truth was his and not sanitised, his approach was broad rather than parochial, and, tending to avoid individual and regimental ephemera, he told a larger story that also touched on the war's impact on the Italian people. His was not a memorial to fallen comrades, for those who did not return - this he left to the regimental historians - but a broader sweep, telling the story with width and context. Much military history is produced by soldiers. By the men who were there. Axelson was there. But he was not a fighting soldier and, for an officer, he seemingly did unorthodox things. He did not steer away from distasteful details, he did not laud high-ranking officers, and he interviewed men and women regardless of role or rank. For these military moguls, Axelson did not speak with an authentic voice. 
Today the wealth of material, both paper and photographic, on the $6^{\text {th }}$ Division in the custody of the military archives in Pretoria, records exactly how much Axelson and his small, yet very capable, staff achieved. Their work is important at several levels. Not only did Axelson oversee and encourage the keeping of war diaries for the full duration of the Italian campaign, but he fostered an interest in others in the writing of personal narratives and regimental history, while he and his team gathered much other historical material for dispatch to Pretoria for later use. His 'running record' of the Division's activities was essentially the first-generation, divisional history written in the field, while his 'log' was his own personal narrative of the campaign. Axelson, therefore, both gathered the source material for future historians of the Division and the campaign in Italy, and contributed substantially to the writing on this campaign as well. In the immediate post-war years, he assisted some units in bringing their war narratives to publication. No other South African achieved this for this war. He was no doubt 'the most experienced war historian [South Africa] had in the field'. ${ }^{140}$ And yet his work, like that of his colleagues, remains almost unacknowledged to this day. 


\section{Endnotes}

1 Most of the extant material on Italy generated by Axelson, while in Italy and after, is at the Jagger Library of the University of Cape Town. This includes his unpublished manuscripts as well as a reasonable amount of correspondence, which I supplemented with material from the Department of Defence Archives in Pretoria. While there is a considerable overlap, of special importance in Pretoria is the other side of the correspondence with the Department of Defence. For this chapter, where there is such an overlap, I have referred to the material at the Jagger.

Axelson, 'Taranto to the Alps', chap 1, p 1, BC1263 Eric Axelson Papers, C2 Diary of 6 SA Armoured Division, Jagger Library, University of Cape Town Libraries (UCT).

2 Patrick Harries and Christopher Saunders, 'Eric Axelson and the history of Portugal in Africa', South African Historical Journal, vol 39 (Nov 1998), pp 167-175. See also FA Mouton, 'Professor Leo Fouché, the History Department and the Afrikanerization of the University of Pretoria', Collected Seminar Papers, Institute of Commonwealth Studies, vol. 48, pp 92-101.

3 Eric Axelson, South-East Africa 1488-1530 (London: Longmans, 1940).

4 On the role of the information / education officers, see Michael Cardo, 'Fighting a Worse Imperialism': White South African Loyalism and the Army Education Services (AES) during the Second World War', South African Historical Journal, vol 46 (2002), pp 141-174.

5 Personnel file, 45005 Major Eric Victor Axelson, SAIC, Department of Defence (DOD) Archives, Pretoria.

6 John Agar-Hamilton to Axelson, 14 Feb 1944, BC1263 Axelson Papers, C4 Letters from Defence Headquarters to Axelson, UCT.

7 John Agar-Hamilton to Axelson, 14 Feb 1944, BC1263 Axelson Papers, C4, UCT.

8 James Bourhill and Fransjohan Pretorius, 'How the story of the South African experience in the Italian campaign was recorded - and distorted', Historia, vol 57, no 2, Nov 2012, pp 350-77. No use is made of the Axelson Papers.

9 Harries and Saunders, 'Eric Axelson and the history of Portugal in Africa', pp 167-175.

10 Guy Butler, Bursting World: An Autobiography 1936-45 (Cape Town and Johannesburg: David Philip, 1983), pp 209-10.

11 John Agar-Hamilton to Axelson, 3 June 1944, BC1263 Axelson Papers, C4, UCT.

12 Agar-Hamilton to Axelson, 24 Mar 1944, BC1263 Axelson Papers, C4, UCT.

13 Eric Axelson, A Year in Italy: An account of a year as military historian with the South African $6^{\text {th }}$ Armoured Division in Italy, 1944-1945, transcribed by Leycester Walton (Port Elizabeth: EH Walton Packaging Pty (Ltd), no date [2001]).

14 On Agar-Hamilton's life and career see Nicholas Southey and FA Mouton, 'A Volksvreemde historian: JAI Agar-Hamilton and the production of history in an alien environment', South African Historical Journal, vol. 44 (2001), pp 72-98. FA Mouton, History, Historians and Afrikaner Nationalism: Essays on the History Department of the University of Pretoria, 1909-1985 (Vanderbijlpark: Kleio, 2007).

15 Dennis Etheredge to Axelson, 20 June 1944, BC1263 Axelson Papers, C4, UCT.

16 Agar-Hamilton to Axelson, 3 July 1944, BC1263 Axelson Papers, C4, UCT.

17 Jeffrey Grey, "'Standing humbly in the ante-chambers of Clio": the rise and fall of Union War Histories', Scientia Militaria, vol. 30, no. 2 (2000), pp 256-57. 
Agar-Hamilton to Axelson, 21 June 1944, BC1263 Axelson Papers, C4, UCT. See also Jean Walker, Skin Deep; The Autobiography of a woman doctor (Kommetjie: Midgley, 1977), p 93. BC618 Eric Anderson Walker Papers, UCT. On the role and place of Walker in South African history writing, see Christopher Saunders, The Making of the South African Past; Major historians on race and class (Cape Town and Johannesburg: David Philip, 1988), pp 112-15; and Ken Smith, The Changing Past; Trends in South African historical writing (Johannesburg: Southern, 1988), pp 121-31.

19 Agar-Hamilton to Axelson, 28 Jul 1944, BC1263 Axelson Papers, C4, UCT; and quoted in Axelson, 'Preface', Taranto to the Alps, BC1263 Axelson Papers, C2, UCT. Axelson, 'Preface', Taranto to the Alps, BC1263 Axelson Papers, C2, UCT. Agar-Hamilton to Axelson, 14 Feb 1944, BC1263 Axelson Papers, C4, UCT. Axelson, 'Preface', Taranto to the Alps, BC1263 Axelson Papers, C2, UCT. Agar-Hamilton to Axelson, 24 Mar 1944, BC1263 Axelson Papers, C4, UCT. Agar-Hamilton to Axelson, 18 Feb 1944, BC1263 Axelson Papers, C4, UCT. Agar-Hamilton to Axelson, 18 Feb 1944, BC1263 Axelson Papers, C4, UCT. Daily log, 1 June 1944, BC1263 Axelson Papers, C2, UCT. Daily log, 9 Jul 1944, and 4 Oct 1944, BC1263 Axelson Papers, C2, UCT. Axelson, 'Preface', Taranto to the Alps, BC1263 Axelson Papers, C2, UCT. Grey, "Standing humbly in the ante-chambers of Clio": the rise and fall of Union War Histories', p 262.

30 There were a number of officials that had to keep a war diary: each branch of the staff in the headquarters of a formation, a subordinate command and area or sub-area on the lines of communication; all unit commanders; commanders of detachments of a headquarters or unit; all base, auxiliary, and advanced commanders; and the heads of services and their representatives. In the case of headquarters, sections of the various branches were permitted to keep separate war diaries or one combined war diary, as they found to be convenient.

31 Information that might be contained in the Narrative of a war diary: 'Account of operations with notes of topographical and climatic factors affecting them; Notes of how orders were carried out; Nature and description of filed engineering works constructed; Note of any administrative difficulties encountered and action taken to overcome them; Note of how time not accounted for above was spent. The type of training, etc., should be specified; Brief notes of the times of receipt and issue of orders and important messages, and a reference to the appendix letter and folio number; and, only if necessary, a very brief note of the contents; Intermediate movements of unit or formation; and Notes of any important visits paid and received by Commanders and Senior Staff Officers. It is equally important to make a note of the reason for the visit and decisions taken.' Instruction UDF/930/6 dated 25 Jan 1945 on War Diaries, Historical Survey of 1 (SA) L of C Field Security Section, SA Intelligence Corps, War Diaries, box 724, DOD Archives. Daily log, 31 Jan 1945, BC1263 Axelson Papers, C2 Diary of the historical recording officer, 6 SA Armoured Division, 1944-1945, UCT. Daily log, 20 Jul 1944, BC1263 Axelson Papers, C2, UCT. Daily log, 20 Jul 1944, BC1263 Axelson Papers, C2, UCT. Daily log, 14 Jul 1944, BC1263 Axelson Papers, C2, UCT. Daily log, 9 Jul 1944, BC1263 Axelson Papers, C2, UCT.

38 Gustav Bentz, 'Fighting Springboks: C Company, Royal Natal Carbineers from Premier Mine to the Po Valley, 1939-1945' (Stellenbosch University: MMil thesis, 2013), p 131. 
Daily log, 31 Jan 1945, BC1263 Axelson Papers, C2, UCT.

Dennis Etheredge to Axelson, 20 June 1944, BC1263 Axelson Papers, C4, UCT. Instruction UDF/930/6 dated 25 Jan 1945 on War Diaries, Historical Survey of 1 (SA) L of C Field Security Section, SA Intelligence Corps, War Diaries, box 724, DOD Archives.

41 Neil Orpen, Victory in Italy (Cape Town and Johannesburg: Purnell, 1975), p 8.

2 PR Anderson, 'On Photographs at War: Images of the South African 6th Armoured Division in Italy 1944-1945', Safundi: The Journal of South African and American Studies, vol. 15, no. 2-3 (2014), 197-225.

Dennis Etheredge to Axelson, 20 June 1944, Deputy Chief of Staff to GOC 6 SA Armd Div, 21 June 1944, Agar-Hamilton to Axelson, 21 June 1944 and 3 July 1944, BC1263 Axelson Papers, C4, UCT.

Ray Ryan, Memories of Italy World War II (Cape Town: McKerrow Atkins, 1982), p vi. Daily log, 7 June 1944, BC1263 Axelson Papers, C2, UCT. Daily log, 30 June 1944, BC1263 Axelson Papers, C2, UCT.

See for example, Bob Connolly, The Bob Connolly Story (Cape Town: Howard Timmins, undated).

In June 1944, for example, he was 'accompanied by a flush of war correspondents', believing that Axelson would find the best 'vantage point' from which to view the coming action. Axelson, 'Taranto to the Alps', chap 2, p 6, BC1263 Axelson Papers, C2, UCT.

Daily log, 8 - 9 Jul 1944, BC1263 Axelson Papers, C2, UCT.

Agar-Hamilton to Axelson, 21 June 1944, BC1263 Axelson Papers, C4, UCT.

Agar-Hamilton to Axelson, 24 Mar 1944, BC1263 Axelson Papers, C4, UCT.

Daily log, 6 Jul 1944, BC1263 Axelson Papers, C2, UCT.

Daily log, 8 - 9 Jul 1944, BC1263 Axelson Papers, C2, UCT.

Daily log, 16 Jul 1944, BC1263 Axelson Papers, C2, UCT.

Daily log, 16 Jul 1944, BC1263 Axelson Papers, C2, UCT.

Fankie Monama, 'Wartime Propaganda in the Union of South Africa 1939-1945'

(Stellenbosch University: PhD dissertation, 2014), pp 92-97.

Agar-Hamilton to Axelson, 14 Feb 1944, BC1263 Axelson Papers, C4, UCT.

Agar-Hamilton to Axelson, 28 July 1944, quoted in Axelson, A Year in Italy, p 233.

Agar-Hamilton to Axelson, 26 May 1944, BC1263 Axelson Papers, C4, UCT.

The emphasis is Agar-Hamilton's.

Axelson, A Year in Italy, p 235.

61 On the governmental publicity programmes see Fankie Monama, 'Wartime Propaganda in the Union of South Africa 1939-1945' (Stellenbosch University: PhD dissertation, 2014).

Daily log, 9 - 10 Jul 1944, BC1263 Axelson Papers, C2, UCT.

Daily log, 19 Jul 1944, BC1263 Axelson Papers, C2, UCT.

Agar-Hamilton to Axelson, 14 Feb 1944 and 15 May 1944, BC1263 Axelson Papers, C4, UCT.

Agar-Hamilton to Axelson, 19 Apr 1944, BC1263 Axelson Papers, C4, UCT.

Maj HC Weaver, OC Film Unit, to Agar-Hamilton, 4 May 1944, and Agar-Hamilton to Axelson, 9 May 1944, BC1263 Axelson Papers, C4, UCT.

John Agar-Hamilton to Axelson, 3 June 1944, BC1263 Axelson Papers, C4, UCT. 
Daily log, 12 Jul 1944, BC1263 Axelson Papers, C2, UCT.

Daily log, 16 Jul 1944, BC1263 Axelson Papers, C2, UCT.

Agar-Hamilton to Axelson, 20 Jan 1961, BC1263 Axelson Papers, B1(A), UCT.

Deputy Chief of Staff to GOC 6 SA Armd Div, 8 Mar 1944, BC1263 Axelson Papers, C4, UCT.

Agar-Hamilton to Axelson, 30 May 1944, BC1263 Axelson Papers, C4, UCT.

Daily log, 11 June 1944, BC1263 Axelson Papers, C2, UCT. This was sent to Historical Records and the original may be found in the Narratives and Reports (Nareps) collection of the Union War Histories archive, box 142. I am grateful to Evert Kleynhans for this reference.

Daily log, 26 June 1944, BC1263 Axelson Papers, C2, UCT.

Daily log, 30 June 1944, BC1263 Axelson Papers, C2, UCT.

Axelson, 'The Sixth South African Armoured Division in Italy up to the fall of Florence', Aug 1944, Narep CMF 2, UWH, box 141, DOD Archives, Pretoria.

Daily log, 30 June 1944, BC1263 Axelson Papers, C2, UCT.

Agar-Hamilton to Axelson, 3 July 1944, BC1263 Axelson Papers, C4, UCT. Brig E.P. Hartshorn, Avenge Tobruk (Cape and Johannesburg: Purnell, 1960), p 179.

Deputy Chief of Staff to GOC 6 SA Armd Div, 8 Mar 1944, and Agar-Hamilton to Axelson, 24 Mar 1944, BC1263 Axelson Papers, C4, UCT.

Samuel Hynes, The Soldiers'Tale; Bearing Witness to Modern War (London: Pimlico, 1998), p 25.

For an alternate view see Bourhill and Pretorius, 'How the story of the South African experience', p 354.

Instruction UDF/930/18 dated 7 Jun 1945 on War Diaries, Historical Survey of 1 (SA) L of C Field Security Section, SA Intelligence Corps, War Diaries, box 724, DOD Archives.

Instruction UDF/930/18 dated 7 Jun 1945 on War Diaries, Historical Survey of 1 (SA) L of C Field Security Section, SA Intelligence Corps, War Diaries, box 724, DOD Archives.

4 Historical Survey of 1 (SA) L of C Field Security Section, SA Intelligence Corps, WD, box 724, DOD Archives.

Diary, 9 Jul 1944, BC1263 Axelson Papers, C2, UCT.

South African troops were reported to have done 'a considerable amount of looting in Chiusi. There was also a particularly bad case, where three people had been murdered and a woman raped.' Daily log, 27 - 28 June 1944, BC1263 Axelson Papers, C2, UCT. Diary, 10 - 15 Jul 1944, BC1263 Axelson Papers, C2, UCT.

Axelson, A Year in Italy, p 109.

Orpen, Victory in Italy, p 169.

Axelson, A Year in Italy, p 133.

See, for example, DV Jeffrey, The $8^{\text {th }}$ Field Squadron (Johannesburg: Rostra Printers, c. 1946); LG Murray, First City / Cape Town Highlanders in the Italian Campaign, 1943-1945 (Cape Town: Cape Times, 1946);TR Ponsford, War Record of Union Defence Force Institutes (YMCA - Toc H) (Cape Town: Hortor's, c. 1946); RW Tungay, The Fighting Third (Cape Town: 1947); JN Cowin, The Story of the Ninth; A Record of the $9^{\text {th }}$ Field Company, South African Engineer Corps, July 1939 to July 1943 (Johannesburg: 1948); and SE van Broembsen, The story of men; $A$ brief history of the Regiment De la Rey and the Witwatersrand Rifles and their association (Potchefstroom:The Potchefstroom Herald, 1948). 
92 John Agar-Hamilton to Axelson, 3 June 1944, BC1263 Axelson Papers, C4, UCT.

93 Agar-Hamilton to Axelson, 21 June 1944, BC1263 Axelson Papers, C4, UCT.

94 Axelson, 'Taranto to the Alps', p 2-11, BC1263 Axelson Papers, C2, UCT.

95 Daily log, 1 June 1944, BC1263 Axelson Papers, C2, UCT.

96 Daily log, 1 June 1944, BC1263 Axelson Papers, C2, UCT.

97 Daily log, 1 June 1944, BC1263 Axelson Papers, C2, UCT.

98 Daily log, 1 June 1944, BC1263 Axelson Papers, C2, UCT.

99 Axelson, $A$ Year in Italy, 17.

100 Axelson, $A$ Year in Italy, p 121.

101 Report of Historical Recording Officer for month ended 31 Aug 1944, War Diaries, box 599, DOD Archives, Pretoria.

102 Daily log, 12 Jul 1944, BC1263 Axelson Papers, C2, UCT.

103 Agar-Hamilton to Axelson, 15 May 1944, BC1263 Axelson Papers, C4, UCT.

104 Daily log, 21 Jul 1944, BC1263 Axelson Papers, C2, UCT.

105 Collyer to Secretary for Defence, 4 Jul 1936, file 101 SWA Campaign Preparation of Military Textbook by Gen Collyer, GOC UDF, box 18, DOD Archives.

106 Italian Campaigns: a patrol-night 18/19 May 1944 as seen by Division Recording Officer, BC1263 Axelson Papers, C3, UCT.

107 Agar-Hamilton to Axelson, 24 Aug 1944, BC1263 Axelson Papers, C4, UCT.

108 Axelson to Agar-Hamilton, 30 Aug 1944, Narep CMF 2, UWH, box 141, DOD Archives.

109 Eric Axelson, 'The Sixth South African Armoured Division in Italy; A provisional outline account for use by Historical Recording Section only, Aug 1944', Narep CMF 2, UWH, box 141, DOD Archives.

110 Agar-Hamilton to Axelson, 26 Sep 1944, BC1263 Axelson Papers, C4, UCT.

111 'The Sixth South African Armoured Division in Italy, A provisional outline account', pp 92-93, War Diaries, box 598, DOD Archives, Pretoria.

112 'The Sixth South African Armoured Division in Italy, Part II: 22 Aug 44 - 24 Feb 45', War Diaries, box 598, DOD Archives, Pretoria.

113 Axelson, 'Preface', Taranto to the Alps, BC1263 Axelson Papers, C2, UCT.

114 Axelson, A Year in Italy, p 233.

115 Axelson, $A$ Year in Italy, p 234.

116 Axelson, A Year in Italy, p 237.

117 Morrilo and Pavkovic.

118 Agar-Hamilton to Axelson, 26 Dec 1960, BC1263 Axelson Papers, B1(A), UCT.

119 Agar-Hamilton to Axelson, 30 May 1944, BC1263 Axelson Papers, C4, UCT.

120 On the Bureau of Information, its activities, and the government information campaign, see Fankie Monama, 'Wartime Propaganda in the Union of South Africa 1939-1945' (Stellenbosch University: PhD dissertation, 2014).

121 Colonel EO Maggs to DCS, with a copy to Axelson, 8 Jun 1945, War Diaries, box 598, DOD Archives, Pretoria.

122 Interview with Maj I Moore, Brigade Major, $12^{\text {th }}$ SA Mot Bde, undated, UWH, box 142, DOD Archives, Pretoria. 
123 Sir Andrew Macphail quoted by Tim Cook, 'Literary Memorials: The Great War Regimental Histories, 1919-1939', Journal of the Canadian Historical Association, vol. 13 (2002), p 167.

124 Colonel EO Maggs to DCS, with a copy to Axelson, 8 Jun 1945, War Diaries, box 598, DOD Archives, Pretoria.

125 Agar-Hamilton to Axelson, 5 Apr 1950, BC1263 Axelson Papers, B8, UCT.

126 Prof EG Malherbe to Axelson, 23 Oct 1951, BC1263 Axelson Papers, B13, UCT.

127 Agar-Hamilton to Axelson, 17 Nov 1951, BC1263 Axelson Papers, B1(A), UCT.

128 "The German Submarine offensive in South African waters", BC1263 Axelson Papers, C6, UCT.

129 Turner left for a university position in Australia in 1947 and Betzler died of a heart attack in 1960, while Michael Roberts 'went on to a distinguished career as Professor of History at Rhodes followed by twenty years at Queen's University, Belfast as the foremost scholar of early modern Sweden and the age of Gustavus Adolphus'. AgarHamilton left when the doors closed in 1961 to take up a position at Rhodes University. Grey, "Standing humbly in the ante-chambers of Clio", pp 253-66. Ian van der Waag, 'Contested histories: official history and the South African military in the $20^{\text {th }}$ century', in J Grey, ed., The Last Word? Essays on Official History in the United States and British Commonwealth (Westport, Connecticut and London: Praeger, 2003), pp 27-52.

130 Harries and Saunders, 'Eric Axelson and the history of Portugal in Africa', pp 167-175. Agar-Hamilton to Axelson, 26 Feb 1962, BC1263 Axelson Papers, B1(A), UCT.

131 See for example Axelson, Portuguese in South-East Africa, 1600-1700 (Johannesburg: Witwatersrand University Press, 1960); Axelson, Portugal and the Scramble for Africa, 1875-1891 (Johannesburg: Witwatersrand University Press, 1967); Axelson, Congo to Cape: Early Portuguese Explorers (Barnes \& Noble, 1973); Axelson, Vasco da Gama: The Diary of His Travels Through African Waters, 1497-1499 (Cape Town: Stephan Phillips, 1998). Most of these enjoyed several editions.

132 Bourhill and Pretorius, 'How the story of the South African experience', p 354.

133 They were Commodore Jean de Villiers and Commodore Hennie Nel. In both cases the theses were published in the Archives Year Book for South African History: Charl Jean de Villiers, 'Die Britse vloot aan die Kaap, 1795 - 1803' (UCT: MA thesis, 1967), vol. 32, part I, 1969; and HF Nel, 'Die Britse verowering van die Kaap in 1795’ (UCT: MA thesis, 1967), vol. 35, part II, 1972.

134 Neil Orpen, Victory in Italy (Cape Town and Johannesburg: Purnell, 1975). Gerald Shaw, The Cape Times; An Informal History (Cape Town: David Philip, 1999), p 129.

135 Agar-Hamilton to Axelson, 26 Dec 1960, B1(A), BC1263 Axelson Papers, UCT.

136 In his list of sources, Orpen mentions the Union War Histories documents as a single class on one line; no details are given and Axelson's name does not appear in the book. The authorities Orpen cites are also almost entirely restricted to published books, including regimental histories and personal accounts. Orpen, Victory in Italy, p 311.

137 JJ Bruwer, 'Die Rol van die Sesde Suid-Afrikaanse Pantserdivisie in Italië, 27 May tot 4 Augustus 1944' (Randse Afrikaanse Universiteit: PhD thesis, Nov 1989).

138 Jack Kros, War in Italy; With the South Africans from Taranto to the Alps (Rivonia: Ashanti, 1992).

139 James Bourhill, Come back to Portofino; Through Italy with the $6^{\text {th }}$ South African Armoured Division (Johannesburg: 30 Degrees South, 2011).

140 Prof EG Malherbe to Axelson, 23 Oct 1951, BC1263 Axelson Papers, B13, UCT. 